\title{
Effect of Transition Element Addition on the Microstructure and Microhardness of (Al-Si-Cu) Aged Alloys
}

\author{
H. M. Medrano-Prieto ${ }^{1}$, C.G. Garay-Reyes ${ }^{1}$, M.A. Ruiz-Esparza-Rodriguez ${ }^{1}$, I. Estrada-Guel ${ }^{1}$, M. C. \\ Maldonado-Orozco ${ }^{2}$ and R. Martínez-Sánchez ${ }^{1}$ \\ ${ }^{1 .}$ Centro de Investigación en Materiales Avanzados (CIMAV), Laboratorio Nacional de Nanotecnología, \\ Chihuahua, Chih., México. \\ 2. Universidad Autónoma de Chihuahua (UACH), Facultad de Ingeniería, Circuito No. 1, Nuevo Campus \\ Universitario, Chihuahua, Chih., México.
}

The A319 alloy is based in Al-Si system, its principal characteristics are high castability to produce parts with complex forms due to Si content, good machinability, light weight and optimal combination of strength and ductility. Their major applications are in the automotive industry as a material to manufacture pistons, engine blocks and cylinder heads. The T6 heat treatment is used to improve the mechanical performance of such components due to the precipitation of $\theta^{\prime}$ and $\theta^{\prime \prime}-\mathrm{Al}_{2} \mathrm{Cu}$ semi-coherent and metastable phases during aging treatment. Some transition metals like $\mathrm{Ni}$ and $\mathrm{Fe}$, and some rare earths like $\mathrm{Ce}$, have been used in aluminum alloys to reduce the coefficient of thermal expansion and improve the mechanical properties at relative high temperatures [1]. For example, additions of 1 to $2 \%$ Ni to 2xxx and 3xxx series alloys improve hardness and tensile properties at elevated temperatures [2]. Hayajneh et al. [3] and others investigations [4] have been reported the effect of $\mathrm{Ni}$ additions in the hardness properties in $\mathrm{Al}-\mathrm{Cu}$ and $\mathrm{Al}-\mathrm{Si}-\mathrm{Cu}$ alloys respectively; they reported that the formation of the Al-Ni, Al-Ni-Cu intermetallic compounds have a direct relationship with mechanical properties and a significant delay in the loss of hardness values during the over-aging stage.

This investigation under takes the changes of microstructure by the Ni additions and heat treatments in A319 alloy. The evolution in the microstructure was characterized by TEM. The mechanical properties were evaluated using Vickers microhardness test in accordance with the ASTM standards The A319 alloy and those with $\mathrm{Ni}$ additions were solution heat treated at $495^{\circ} \mathrm{C}$ for $7 \mathrm{~h}$, quenching in water at 60 ${ }^{\circ} \mathrm{C}$ and aged at $170{ }^{\circ} \mathrm{C}$ for $0.5,3,5,10$ and $96 \mathrm{~h}$.

Fig. 1 shows the behavior of the hardness values respect to Ni content and aging time in A319 alloy. It is observed increments of hardness values in function of increments of $\mathrm{Ni}$, the hardness peaks are observed at $240 \mathrm{~min}(4 \mathrm{~h})$ for 1-2 $\mathrm{Ni}(\mathrm{wt} . \%$ ) and remain stable up to $10 \mathrm{~h}$. The Ni additions in A319 alloy favors the increments in $\mathrm{HV}$ values and the peaks of hardness appear at shorter aging time. Additionally, in samples alloyed with $\mathrm{Ni}$ the $\mathrm{HV}$ values decreases slowly during over-aging stage. Furthermore, the $\mathrm{Ni}$ addition 1-2 $\mathrm{Ni}$ (wt. \%) to the A319 alloy have an significant effect on the microstructure; principally in the morphology, size, distribution and number density of $\theta-\mathrm{Al}_{2} \mathrm{Cu}$ precipitates formed during aging heat treatment (Fig. 2).

\section{References:}

[1] Jack W Bray in "Properties and Selection: Non Ferrous Alloys and Special Purpose Materials", 10 ed. (ASM International, USA) p. 165.

[2] R. S. Rana, Rajesh Purohit, and S Das, Int. J. Sci. Res. Pub 2 (2012), p. 1. 
[3] Mohammed T. Hayajneh, Adel Mahamood Hassan, Younis Mohammad Jaradat, Academia.edu 141 (2007), p. 1.

[4] Hansel Manuel Medrano-Prieto et al, Mater. Res. 19 (2016), p. 59.

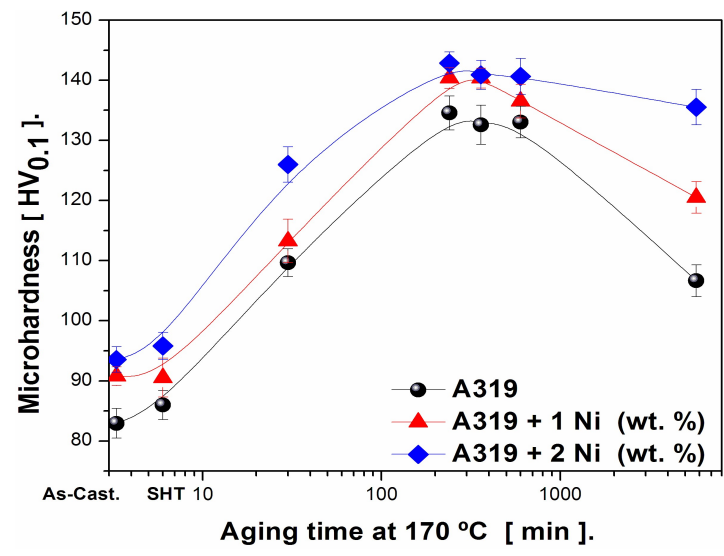

Figure 1. Vickers microhardness versus aging time for the A319 alloy and those with Ni additions, after $7 \mathrm{~h}$ of SHT at $495^{\circ} \mathrm{C}$ and aged at $170{ }^{\circ} \mathrm{C}$ for different times.

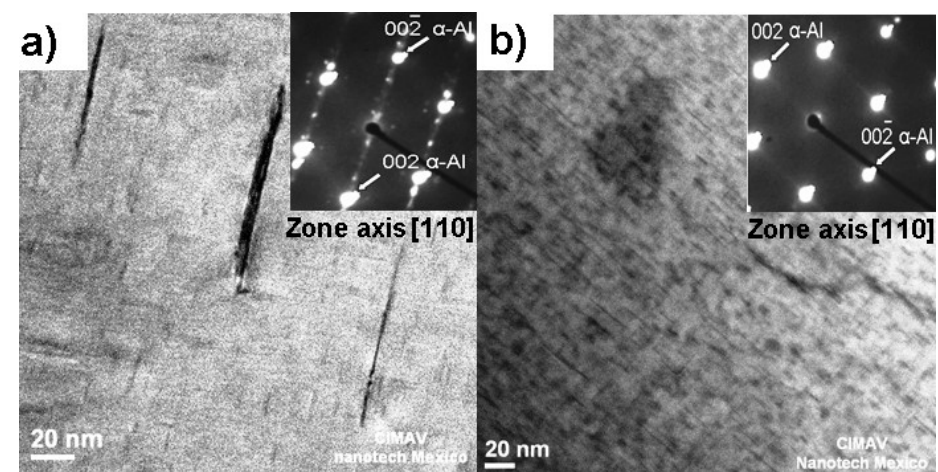

\section{c)}

d)

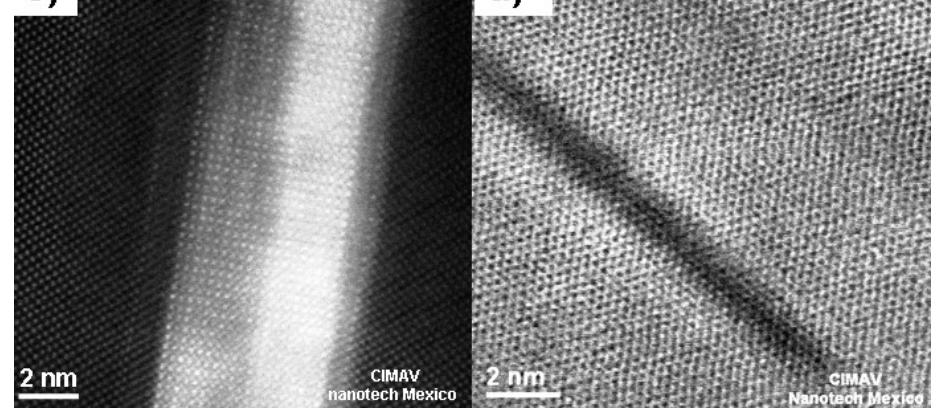

Figure 2. TEM Micrographs of A319 alloy and those with $2 \mathrm{Ni}$ (wt. \% ) additions after $7 \mathrm{~h}$ of SHT at $495{ }^{\circ} \mathrm{C}$ and aged for $10 \mathrm{~h}$ at $170{ }^{\circ} \mathrm{C}$. a) and b) Bright field (BF) STEM micrographs of reference alloy and with $\mathrm{Ni}$ addition respectively, c) Z-contrast HRSTEM micrograph of $\theta^{\prime}-\mathrm{Al}_{2} \mathrm{Cu}$ precipitate in reference alloy and d) Bright field (BF) HRSTEM micrograph of full coherent $\theta^{\prime \prime}-\mathrm{Al}_{2} \mathrm{Cu}$ precipitate in alloy modified with $\mathrm{Ni}$. 